mammary cancer compare with those of normal mammary glands remains to be determined.

It is unsafe at present to try to explain why such an outspoken difference was noted between the nuclei of sareomatous cells and those of normal fibroblasts in the tissue cultures examined, while a similar difference could not be detected in pieces of excised tumors. The results are merely reported as they stand for the present without interpretation.

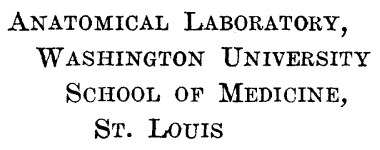

\section{THE PLEISTOCENE ELEPHANTS OF SANTA ROSA ISLAND, CALIFORNIA ${ }^{1}$}

W. G. BLUN's's discovery of fossil teeth of an elephant on Santa Rosa Island, one of the Channel Islands off the coast of southern California, was recorded by Stearns ${ }^{2}$ in 1873 . Since that time this interesting and significant occurrence has been referred to by several authors. Hay ${ }^{3}$ has recently summarized the available information and recognizes the presence of Elephas imperator and of an undetermined species.

During the past year Dr. Spencer Atkinson and Mr. J. A. Barbieri, of Pasadena, secured a fragmentary elephant skull on Santa Rosa Island and presented the specimen to the California Institute of Technology. Through the courtesy of the Vail Company of Los Angeles, owners of the island, the California Institute, with the cooperation of the Carnegie Institution of Washington, have been given the opportunity to investigate the occurrence, and facilities were kindly made available to collect further remains.

Santa Rosa Island is the second largest of four islands separated from the mainland by the Santa Barbara Channel, which has an average width of twenty miles and an average depth of approximately six hundred feet. The geology of this insular area has been recently studied by Kew. ${ }^{4}$ The Pleistocene deposits in which the elephant remains were found occur in the northwestern portion of the island, where they are well exposed in the sea-cliffs and are eroded into bad lands along the stream courses or canadas. These deposits are largely of terrestrial origin and

1 Paper read in part at the meeting of the Cordilleran section, Geological Society of America, Berkeley, California, March 3, 1928.

2 Stearns, R. E. C., Proc. Calif. Acad. Sci., Vol. 5, p. 152, 1873.

3 Hay, O. P., Carnegie Inst. Wash. Pub. 322B, pp. 42, 43 and 51, 1927.

4 Kew, W. S. W., Bull. Geol. Soc. Amer., Vol. 38, pp. 645-654, 1927. consist of clays, sands and gravels, reaching a thickness in places of more than seventy-five feet. At one locality a whale vertebra was found at the base of the Pleistocene strata. The beds rest with marked unconformity upon northward-dipping, marine Miocene sandstones and shales and have suffered little or no deformation. Since their accumulation, however, the Pleistocene beds have been subjected to subsidence, planation and uplift, for at least one well-defined terrace cut into the deposits is now situated at an elevation of seventy-five feet above sea-level. On this terraced surface occur sand dunes and shell mounds in which Indian burial sites are frequently encountered.

The collections secured by the California Institute include a number of teeth, parts of skulls and skeletal material. Occasionally several skeletal elements and teeth are found associated in the deposits. Usually the remains are scattered. One curious feature of the occurrence is the apparent total absence of associated mammalian types. The proboscidean remains are referable to the genus Elephas. The individuals exhibit considerable variation in size, and this is undoubtedly to be aseribed in part to differences in age. A survey of the collection as a whole yields the impression rather strongly that the elephant types were of relatively small size. Some of the forms may have a height of six to eight feet as measured at the shoulder. The larger individuals are perhaps comparable in size to the American mastodon and are certainly smaller, possibly considerably smaller, than the Pleistocene mammoths of the southwestern United States.

While the Santa Rosa Island elephant has been determined as representing the species Elephas primigenius Blumenbach and E. (Archidiskodon) imperator Leidy, the difference in size, coupled with differences noted in the skull and dentition, seem quite clearly to distinguish the island form as a distinet species for which the name Elephas exilis is here proposed. The type of the species is No. 14 Calif. Inst. Tech. Coll. Vert. Pale., a skull and mandible including four cheekteeth and two tusks. A fuller description of the species will be published elsewhere.

The relatively small size of the Pleistocene elephants of this region suggests the interesting possibility of a dwarfing of these forms induced by insular isolation. This brings to mind the occurrence of the pigmy elephant Elephas melitensis Falconer in the bone caverns of Malta and of the related E. mnaidriensis Adams of Sicily, types which have become classic in paleontological literature as examples of a dwarfing of large mammals resulting from island isolation. While the factor of isolation may have been influential in producing the characters exhibited by the Santa Rosa Island elephant, it should be clearly recognized 
that no definite evidence is at hand to indicate that the forms were not small when, during Pleistocene time, the distribution of these types extended westward into the region now occupied by the Channel Islands, unless that evidence rests on the failure to identify similar forms in Pleistocene deposits on the mainland.

The presence of Pleistocene elephants on Santa Rosa Island furnishes apparently a striking confirmation of the view that profound ehanges in the coast line of southern California have occurred in late geological time.

\section{Chester Stock}

E. L. FURLONG

\section{California Instifute of Technologx}

\section{A COLLECTION OF ANAEROBIC BACTERIA}

DURING the past sixteen years I have devoted much time to collecting, identifying and studying anaerobic bacteria. My interest in these micro-organisms grew out of the fact that all the bacteriologists whom I knew in 1912 threw up their hands when anaerobic bacteria were mentioned; not one understood how to isolate an obligate anaerobe from a mixed culture with any degree of precision or how to identify one afterward. In the same year I was fortunate enough to be ássigned the task of developing a tetanus antitoxin laboratory for the Cutter Biological Laboratory in Berkeley, California. Tetanus antitoxin had never been made anywhere in the western United States previously, and this laboratory was the first to undertake it. During the following year, about the time we had successfully completed the immunization of our first horses, I met Dr. K. F. Meyer, who had just been appointed associate professor of bacteriology in the University of California. Dr. Meyer was the first bacteriologist of my acquaintance who seemed to know anything about the obligate anaerobes, and while I have never been directly associated with him in his laboratory, notwithstanding he was both my predecessor and successor at Berkeley, I am glad to acknowledge his valuable guidance on numerous occasions.

The early phase of my studies involved securing so-called "type cultures" from as many sources as possible, and the development of my own technic in checking the purity and identity of these. A few of these cultures were pure and correctly named, but some of them were impure and many were misnamed. It was not until Weinberg and Seguin's memorable monograph "La Gangrene Gazeuse" (1917) became available in 1920 that we were able to recognize with any degree of certainty any but a few of the commonest species in the collection, which then numbered sixty-three strains.
I have continued to add new strains to the collection, partly by aceretion from other laboratories, but mainly by isolation from original materials, soil, water, milk, accidental contaminations of culture media, spontaneous infections in laboratory animals, and particularly during the past five years from human sources, both ante- and post-mortem.

The collection now contains 319 strains, 282 of which have been at least tentatively purified and identified, while thirty-seven other non-pathogenic strains have been presumably purified but not identified. Some of the latter possibly represent new species, others are probably species whose descriptions are buried in obscure or unavailable scientific articles. These obviously offer excellent material for further taxonomic research in this group.

Among those that have been identified are the following species, those that are definitely pathogenic being starred thus *. In a few instances the identification is only tentative.

\begin{tabular}{|c|c|c|}
\hline B. bifermentans & & rains \\
\hline *B. botulinus, Type A & 4 & 6 \\
\hline${ }^{*}$ B. botulinus, Type B & 4 & “6 \\
\hline $\begin{array}{l}\text { B. butylicus, B. amylobacter, B. butyricus } \\
\text { and related species }\end{array}$ & 9 & 66 \\
\hline B. centrosporogenes & 28 & 66 \\
\hline${ }^{*}$ B. chauvoei & 4 & 66 \\
\hline 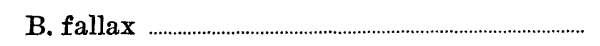 & 1 & 66 \\
\hline B. flabelliferum ......................... & 4 & 66 \\
\hline${ }^{*}$ B. hemolyticus ............ & 1 & “6 \\
\hline${ }^{*} \mathrm{~B}$. histolyticus .............. & 13 & 66 \\
\hline B. multifermentans & 9 & 6 \\
\hline B. non-fermentans & 2 & “6 \\
\hline *B. Novyi & 8 & ، \\
\hline${ }^{*}$ B. oedematoides & 3 & 66 \\
\hline B. putrefaciens & 4 & “6 \\
\hline B. putrificus (and B. cochlearius?) & 8 & ، \\
\hline${ }^{*}$ B. septicus & 14 & 66 \\
\hline *B. Sordellii & $\mathbf{3}$ & 6 \\
\hline B. sporogenes & 32 & $\therefore$ \\
\hline B. sphenoides & 1 & 6 \\
\hline B. sub-terminalis ................... & 1 & “ \\
\hline B. tertius & 15 & “ \\
\hline *B. tetani & 24 & ، \\
\hline B. tetanomorphus & $\mathbf{3}$ & 66 \\
\hline B. tyrosinogenes & 1 & ، \\
\hline *B. Welchii & 40 & “ \\
\hline Fusiformis (Sp. \&) & 3 & “ \\
\hline M. gazogenes & 37 & “6 \\
\hline ntified strains & 282 & \\
\hline
\end{tabular}

The number of strains of each species in the collection gives a clue, in a sense, to the frequency with which one who collects anaerobes in much the same spirit as an amateur entomologist collects butterflies 


\section{Science}

\section{THE PLEISTOCENE ELEPHANTS OF SANTA ROSA ISLAND, CALIFORNIA}

Chester Stock and E. L. Furlong

Science 68 (1754), 140-141.

DOI: $10.1126 /$ science.68.1754.140

ARTICLE TOOLS

REFERENCES

PERMISSIONS http://science.sciencemag.org/content/68/1754/140

This article cites 3 articles, 1 of which you can access for free http://science.sciencemag.org/content/68/1754/140\#BIBL

http://www.sciencemag.org/help/reprints-and-permissions

Science (print ISSN 0036-8075; online ISSN 1095-9203) is published by the American Association for the Advancement of Science, 1200 New York Avenue NW, Washington, DC 20005. The title Science is a registered trademark of AAAS.

Copyright (C) 1928 The Authors, some rights reserved; exclusive licensee American Association for the Advancement of Science. No claim to original U.S. Government Works. 